\title{
Tourists' Preferences toward Ecotourism Development and Sustainable Biodiversity Conservation in Protected Areas of Vietnam - The Case of Phu My Protected Area
}

\author{
Duyen Thi Thu Tran ${ }^{1}$, Hisako Nomura ${ }^{2} \&$ Mitsuyasu Yabe ${ }^{2}$ \\ ${ }^{1}$ School of Economics and Business Administration, Can Tho University, Can Tho, Vietnam \\ ${ }^{2}$ Faculty of Agriculture, Kyushu University, Fukuoka, Japan \\ Correspondence: Duyen Thi Thu Tran, School of Economics and Business Administration, Can Tho University, \\ Campus 2, 3/2 Street, Xuan Khanh Ward, Ninh Kieu District, Can Tho City, Vietnam. Tel: 84-943-324-603. \\ E-mail: tranthithuduyen87@gmail.com; thuduyen@ctu.edu.vn
}

Received: January 25, 2015 Accepted: May 11, 2015 Online Published: July 15, 2015

doi:10.5539/jas.v7n8p81 URL: http://dx.doi.org/10.5539/jas.v7n8p81

\begin{abstract}
Ecotourism has been more and more promoted in many countries because it contributes to nature conservation, eco-education and income generation for local community. Vietnam has a great potential of ecotourism resources with a large system of national parks and protected areas, however the development of ecotourism in protected areas in Vietnam is not corrective to its potential. This paper analyzes tourists' preferences for ecotourism services and biodiversity conservation in a protected area in Vietnam (the case in Phu My protected area) to support the decision-makers in ecotourism development process and nature conservation in the protected area in Vietnam. Choice experiments are employed to examine tourists' interests in ecotourism services and estimate their willingness to pay for these ecotourism services as well as biodiversity conservation. The hypothetical ecotourism tours in the protected area were introduced with 5 attributes, including Crane-watching, craft-market visiting, fishing service, donation for biodiversity conservation and price of ecotourism tour. 199 tourists were interviewed directly and surveyed data were analyzed using Conditional Logit Model. Research results presents that tourists have an interest in the hypothetical ecotourism and prefer to enjoy all above ecotourism services. And tourist's marginal willingness to pay for each ecotourism service is quite high. The study also reveals that tourists are willing to donate for biodiversity conservation activities in the protected area. Within the levels of donation suggested in the choice set, tourists prefer higher donation level.
\end{abstract}

Keywords: choice experiments, ecotourism, donation

\section{Introduction}

Ecotourism is considered to be an important sustainable development tool because of it is "responsible travel to natural areas that conserves the environment and improves the well-being of local people" (definition of ecotourism by The International Ecotourism Society in 1990 - United Nations Environment Program, 2002). In fact, ecotourism not only provides economic benefits for local communities such as increasing local employment and income, but also make tourists "more aware of nature and more supportive of its conservation via changes in their personal behavior, greater political support and larger financial contributions for such conservation" (Tisdell \& Wilson, 2002a; Tisdell, 2003). Thus, many countries have promoted ecotourism to national parks and protected areas.

Realizing the economic and conservational benefits of ecotourism, Vietnam has promoted ecotourism in national parks and protected areas in recent years. Vietnam has a great potential of ecotourism resources with the various and abundant nature resources and large system of national parks and protected areas (126 forested protected areas, 68 wetland protected areas, 15 marine protected areas - The socialist Republic of Vietnam, 2003). However, the development of ecotourism in protected areas of Vietnam is not corrective to its potential (García-Herrera).

To develop ecotourism in protected areas in Vietnam, understanding tourist demand is essential in order to ensure supply meet demand. Local community who provide ecotourism services need to know tourist preference for ecotourism. On the other hand, to support conservation fund in protected areas, managers here expect the 
financial contribution of tourists to conservation activities. Hence they need information on tourist preference for nature and biodiversity conservation to have suitable funding strategy. This study aims to analyze tourists' preference for ecotourism services and biodiversity conservation in protected areas in Vietnam (The case in Phu My protected area) to support the decision - makers in ecotourism development process and sustainable conservation in protected areas in Vietnam. This could contribute to improving livelihood for communities in rural area, and hence relieving the conflict of competing land and resource use between agriculture and biodiversity conservation. Besides, biodiversity in protected area of Vietnam is conserved and enhanced, which supports agriculture because biodiversity provides essential ecosystem services for sustainable agricultural production (European Union Business and Biodiversity Platform, 2010).

Choice experiment (CE) technique has been applied as a useful approach to analyze tourist preference for ecotourism (Hearne \& Salinas, 2002; Hearn \& Santos, 2005) and tourist preference for biodiversity conservation in protected areas (Biénabe \& Hearne, 2006). After some first studies applied CE for analysis of recreationists' preferences (Adamowicz, Louviere \& Williams, 1994; Boxall, Adamowicz, Swait, Williams, \& Louviere, 1996; Boxall \& Macnab, 2000), this approach has been widely applied to analyze tourist preferences for ecotourism development in protected areas (Chaminuka, Groeneveld, Selomane, \& van Ierland, 2012; Hearne \& Salinas, 2002; Hearne \& Santos, 2005; Naidoo \& Adamowicz, 2005). Furthermore, financial contribution for nature conservation in protected areas - an important aspect of ecotourism promotion - is considered in some CE studies (Biénabe \& Hearne, 2006; Alpízar, Martinsson, \& Nordén, 2014). Our study aims to conclude both important aspects of ecotourism which are financial contributions of ecotourism for livelihood of local community and for biodiversity conservation in order to better support the managers and locals in decision making process. Besides, this study also contributes to limited literature on CEs in Vietnam.

This paper is structured as follows. The next section describes the study area and the use of experiment technique to analyze tourist preference for ecotourism and biodiversity conservation in protected area in Vietnam. Section 3 presents the results and discussion of tourist's preference and valuation on ecotourism services as well as their willingness to donate for conserving biodiversity. And the final section is conclusion and policy implication for ecotourism development and conservation fund.

\section{Method}

\subsection{Choice Experiment Technique}

Choice experiments were initially developed by Louviere and Hensher (1982) and Louviere and Woodworth (1983).

In this study, we suppose tourist $i$ has preferences for a set of $K$ ecotourism tours. Each ecotourism tour is described as a bundle of attributes and attributes' levels. The tourist's utility derived from tour $j$ is $U_{i j}$ and can be divided into two components: deterministic component $V_{i j}$ and error component $e_{i j}$ :

$$
U_{i j}=V_{i j}+\varepsilon_{i j}
$$

The tourist evaluates each tour by its utility, compare them and then choose the one with maximum utility. Hence the probability of the tourist choosing tour $j$ is equal to the probability that the utility of tour $j$ is greater than (or equal to) the utility of tour $k$ :

$$
\operatorname{Prob}_{i j}=\operatorname{Prob}\left(U_{i j} \geq U_{i k}\right) \quad \forall k \in k=1, \ldots, K ; j \neq k
$$

This is equivalent to:

$$
\operatorname{Prob}_{i j}=\operatorname{Prob}\left[\left(V_{i j}+\varepsilon_{i j}\right) \geq\left(V_{i k}+\varepsilon_{i k}\right)\right] \quad \forall k \in k=1, \ldots, K ; j \neq k
$$

Rearrange above equation:

$$
\operatorname{Prob}_{i}=\operatorname{Prob}\left[\left(\varepsilon_{i k}-\varepsilon_{i j}\right) \leq\left(V_{i j}-V_{i k}\right)\right] \quad \forall k \in k=1, \ldots, K ; j \neq k
$$

The error terms are assumed to be independently and identically distributed (IID) and follow a Type 1 extreme value distribution. The form of this distribution as follows,

$$
\operatorname{Prob}\left(\varepsilon_{i k} \leq \varepsilon\right)=\exp (-\exp -\varepsilon)
$$

Under these assumptions, the probability of the tourist choosing tour $j$ out of the set of $K$ tours is estimated with Conditional Logit Model (CLM):

$$
\operatorname{Prob}_{i j}=\frac{\exp V_{i j}}{\sum_{k=1}^{K} \exp V_{i k}} ; k=1, \ldots, j, \ldots, K ; j \neq k
$$

The CLM is estimated by maximum likelihood produces, with the log-likelihood function stated in Equation (6), 
where $y_{i j}$ is equal to 1 if tourist $\mathrm{i}$ chose tour $\mathrm{j}$ and 0 otherwise,

$$
\log L=\sum_{i=1}^{N} \sum_{k=1}^{K} y_{i k} \log \left[\frac{\exp \left(V_{i j}\right)}{\sum_{k=1}^{K} \exp \left(V_{i k}\right)}\right]
$$

$V$ is defined as function of ecotourism attributes $\left(x_{k}\right)$ and price $(p)$ and supposed to be linear form:

$$
V(x, p) A S C+\sum \beta_{k} x_{k}+\beta_{p} p
$$

The total derivative of $V$ is given by $d v=\left(\partial V / \partial x_{k}\right) d x_{k}+(\partial V / \partial p) d p$. Setting $d v=0$ and fixing the attribute $x_{k}$ (other than attribute $x_{j}$ ) also at the initial level, the willingness to pay for one unit attribute $x_{j}$ can be calculated as follows,

$$
M W T P_{x_{j}}=\frac{d p}{d x_{j}}=-\frac{\partial V / \partial x_{j}}{\partial V / \partial p}=-\frac{\beta_{j}}{\beta_{p}}
$$

\subsection{Study Area and Survey Site}

Phu My protected area is located on Kien luong district, Kien Giang province, Vietnam. It belongs to Ha Tien Plain which contains the last and unique large areas of Lepironia grassland in Mekong River Delta, Vietnam. This place not only is high bio-capacity but also contains diversity of both plants and animals, especially Sarus Crane - threatened waterbird species of Vietnam and the world. On the other hand, Phu My wetland also provide base economic for ethnic group who harvest Lepironia grass to produce woven goods (Triet \& Caines, 2007).

This protected area is based on a successful conservation project which started in 2004 with the purpose of protecting this important and unique wetland by implementing a model which combined biodiversity conservation and improving locals' income. This is an "open access" protected area where locals can continue to enter this area to harvest grass in a sustainable manner to produce handicraft for their livelihood. Their products are sold in big cities and exported in many countries. After being implemented this project, not only biodiversity value but also the locals' incomes have been improved (The number of Cranes here have increased year by year, and in 2009 Phu My had the highest number of Cranes in Mekong River Delta, Vietnam) (Triet \& Caines, 2007).

Phu My has potential to create recreational services. With the characteristics of wetland area (different to other regions in Vietnam), ecotourism development here could attract tourists by special ecotourism services. Besides, this area can also provide eco-education for students and eco-tourists. The revenue from ecotourism activities contribute to support fund for the managers of this protected area and help to generate residents' income, which is suitable with the national policy of ecotourism development in protected areas in Vietnam.

\subsection{Choice Design}

The important attributes of ecotourism were decided in the questionnaire based on previous studies and discussion with experts. Then, the draft questionnaire was tested by the pilot survey.

The choice questions included attributes and attribute levels as follows,

$>$ Crane-watching: Tourists could have opportunity to watch Sarus Crane, a rare bird in the Red Book of Vietnam and the world. This attribute had two levels: Crane-watching or no Crane-watching

> Craft-market visiting: Tourist could have chance to see local people produce handicraft and also could join in the process of producing. Producing handicraft is the main and traditional job of women in this area. This attribute also had 2 levels: craft-market visiting or no craft-market visiting.

$>$ Fishing: Tourists could have chance to enjoy fishing and then enjoy the special food cooked from the fish caught. The fish used for fishing area, would be taken from farmer's aquaculture. This attribute had 3 levels: no fishing service, fishing only or fishing service including enjoying special food cooked from fish caught.

$>$ Donation: One of the purposes of ecotourism promotion is increasing the financial self-sufficiency of protected area to maintain nature and biodiversity conservation activities. Beside the expected benefits from ecotourism, some potential negative impacts of tourism on the environment protected area (Tisdell, 2003) have to be carefully concerned and controlled. Although the managers receive the budget for conservation activities, it is still limited. Moreover, the nature and biodiversity conservation need to be concerned and contributed from tourists who are potential polluters. Hence, in this study we want to understand tourist preference for contribution, especially financial contribution, to nature and biodiversity conservation. Thus, in this study we consider tourist's donation (voluntary contribution instead of entrance fee) for biodiversity conservation as an attribute of ecotourism tour. This attribute would be carefully explained to respondents such as the potential 
negative impacts of tourism on nature environment, the need of conservation program and the important role of tourists' contribution so that they could have positive willing to pay for nature conservation because of "awareness and acceptance of environmental need; consequences of personal action; responsibility for personal action; and acceptance of policy initiatives" (Blamey, 1998a). There were four levels for this attribute: 0, 5, 10, 15 thousand VND.

> Price: The total cost of the tour to enjoy above attributes, including donation. This attribute also took 4 levels: 50, 100, 150, 200 thousand VND.

An important assumption we want to emphasize in this study is difference between stakeholders of donation and price. Donation money from tourist would be managed by the managers to use for biodiversity conservation activities only while the price excluding donation would be collected by locals who provided ecotourism services We want to analyze separately two important aspects of ecotourism: how ecotourism benefits local community and how it contributes for biodiversity conservation in the protected area.

Table 1. Ecotourism attribute and attribute levels

\begin{tabular}{ll}
\hline Attribute & Levels \\
\hline Crane-watching & 2 levels: Crane-watching, no Crane-watching \\
Craft-market visiting & 2 levels: craft-market visiting, no craft-market visiting \\
Fishing & 3 levels: no fishing, fishing only, fishing service including enjoying \\
& special food from the fish caught \\
Donation & $0,5,10,15$ (thousand VND) \\
Price & $50,100,150,200$ (thousand VND) \\
\hline
\end{tabular}

Note. The exchange rate is $1 \mathrm{USD}=21,200 \mathrm{VND}(6 / 2014)$.

The combination of all attributes and attribute levels is 192 choice sets. A fractional factorial design was used to reduce the choice sets (Hensher, Rose, \& Green, 2005), and finally 32 choice sets were chosen in the questionnaire. The 32 choice sets were blocked into six segments, so each respondent received five or six choice sets. Each choice set had 3 options including status quo option. Beside choice experiment questions, the questionnaire also includes some questions on respondent's social-economic characteristics, attitude towards biodiversity conservation in protected areas.

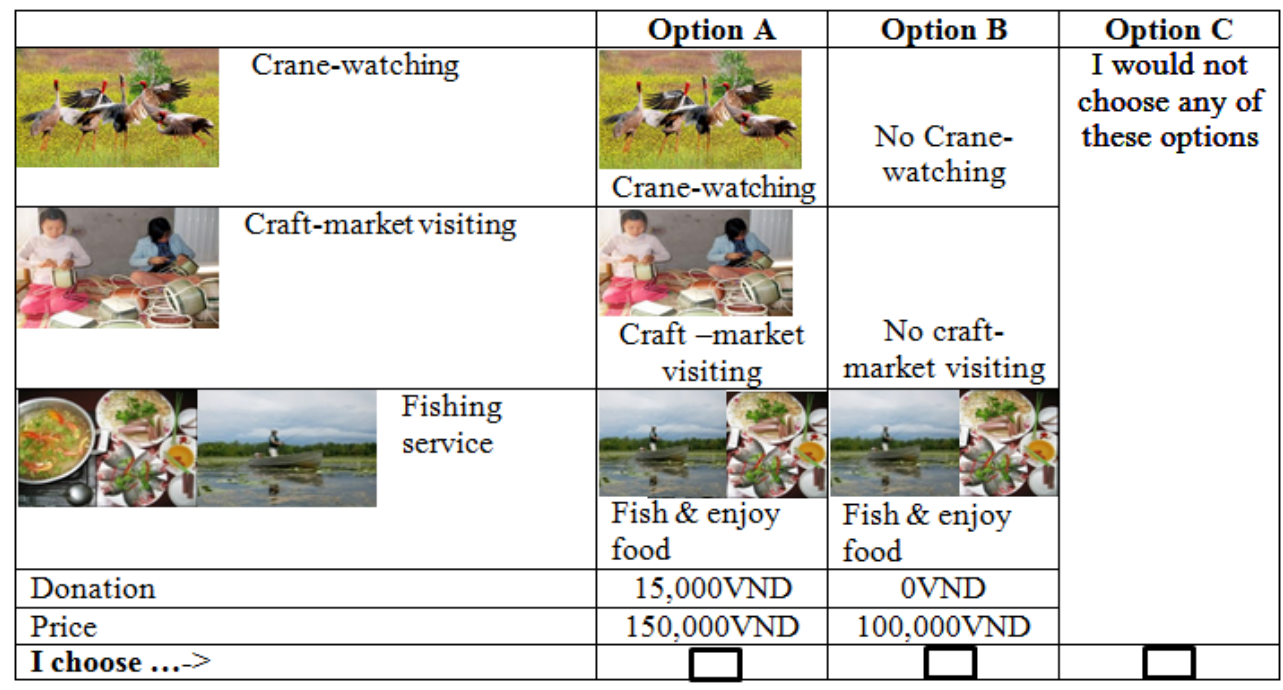

Figure 1. Example of a choice set

\subsection{Data Collection}

Data were collected in two months from August to September 2013. Because Phu My is a new protected area 
and has not been opened for travellers (except researchers and students) to visit, the survey had to be conducted in other tourist area near this place. Ha Tien tourist town, which is $20 \mathrm{~km}$ away from Phu My, was chosen because it is convenient to link two tourist destinations (Ha Tien - Phu My) and thus tourists here will be also potential tourists in Phu My area in the future. Tourists were interviewed directly to fill the questionnaire with clear explanation about the survey purpose, study site and the meaning of multiple choice questions by the interviewers.

\section{Results and Discussion}

\subsection{Socio-Economic Characteristics of Respondents}

Table 2 presents the socio-economic description of the surveyed respondents. The average age of respondents was $32.6 \pm 12.4$ years and about $52 \%$ of respondents were female. The average of household's income was $11.7 \pm 7.9$ million VND per month with the average of household size was $4.9 \pm 2.4$ members. About $42 \%$ of respondents graduated university.

A total of 199 visitors agreed to join in the survey, but only 193 questionnaires were used to analyze in choice experiments because 6 respondents (3\%) were not interested in this hypothetical ecotourism.

Table 2. Socio-economic characteristics of respondents

\begin{tabular}{llll}
\hline Characteristic & Mean & Standard deviation & Percentage \\
\hline Age (years) & 32.6 & 12.4 & \\
Total household's income/month (million VND) & 11.7 & 7.9 & \\
Household size (members) & 4.9 & 2.4 & 51.8 \\
Female & & & 42.2 \\
Education: bachelor or above & & & \\
Total respondents & 199 & & \\
\hline
\end{tabular}

\subsection{Tourist Preferences for Ecotourism Services}

Surveyed data were analyzed using the Conditional Logit Model by software NLOGIT 4.0. The CLM as follows,

$$
\begin{gathered}
V_{1}=A S C+\beta_{1} \text { crane }+\beta_{2} \text { craft }+\beta_{3} \text { fish } 1+\beta_{4} \text { fish } 2+\beta_{5} \text { donation }+\beta_{6} \text { price } \\
V_{2}=A S C+\beta_{1} \text { crane }+\beta_{2} \text { craft }+\beta_{3} \text { fish } 1+\beta_{4} \text { fish } 2+\beta_{5} \text { donation }+\beta_{6} \text { price } \\
V_{3 \text { (base) }}=\beta_{1} \text { crane }+\beta_{2} \text { craft }+\beta_{3} \text { fish } 1+\beta_{4} \text { fish } 2+\beta_{5} \text { donation }+\beta_{6} \text { price }
\end{gathered}
$$

Where, $V_{l}, V_{2}, V_{3}$ are the utility functions associated with option A, B and $\mathrm{C}$ in the choice set. ASC is alternative specific constant, which is representative of the average role of all the unobserved sources of utility, to examine whether or not tourists prefer to enjoy the ecotourism tour regardless of the observed ecotourism attributes. $\beta_{1}, \beta_{2}$, $\beta_{3}, \beta_{4}, \beta_{5}, \beta_{6}$ are the parameters associated with ecotourism attributes: crane, craft, fish1, fish2, donation and price respectively. The ecotourism attributes are described in Table 3 .

Table 3. Description of variables in Conditional Logit Model

\begin{tabular}{ll}
\hline Variable & Definition \\
\hline ASC & Alternative Specific Constant \\
Crane & $1=$ Crane-watching, $0=$ no Crane-watching \\
Craft & $1=$ craft-market visiting, $0=$ no craft-market visiting \\
fish1 & $1=$ fishing only, $0=$ others \\
fish2 & $1=$ fishing service including enjoying special food from the fish caught, $0=$ others \\
Donation & Donation amount (thousand VND) \\
price & Total tour cost to enjoy all above services (thousand VND) \\
\hline
\end{tabular}


We expected all the parameters, except parameter of price, would have positive signs. For donation, because the tourists could get benefit - public benefit and private benefit - from donation (Vesterlund, 2006), the utility of donation was also expected to be positive.

The results of Conditional Logit Model are presented in Table 4. All variables in the model are statistically significant and most of their coefficients, except price, are positive. This suggests that tourists prefer to enjoy in this hypothetical ecotourism with all ecotourism services offered: the crane-watching, craft market visiting, especially fishing service giving the highest marginal utility. The parameter of price is negative, which reveals that tourists prefer a lower price for ecotourism tour. In contrast, donation variable has positive effect on tourist's utility. This interesting point will be discussed further in the next part.

Table 4. Estimated results of Conditional Logit Model

\begin{tabular}{llll}
\hline Variable & Coefficient & Standard Error & P-value \\
\hline ASC & 0.8156 & 0.2503 & 0.0011 \\
crane & 0.9437 & 0.1120 & 0.0000 \\
craft & 0.6800 & 0.1115 & 0.0000 \\
fish1 & 1.3574 & 0.1323 & 0.0000 \\
fish2 & 1.8745 & 0.1384 & 0.0000 \\
donation & 0.0179 & 0.0103 & 0.0827 \\
price & -0.0061 & 0.0011 & 0.0000 \\
Log likelihood & -720.9386 & & \\
\hline
\end{tabular}

Then the marginal willingness to pay for each attribute was calculated by using Equation (8) (see Table 5). Tourists are willing to pay 155 thousand VND for Crane-watching, and 111 thousand VND for craft-market visiting. Fishing service is higher valued with the marginal willingness to pay at 222 thousand VND and 307 thousand VND for fishing service only and fishing service including enjoying special food from the caught fish respectively. If all above services are not ready to provide, tourists are still willing to pay 134 thousand VND to enjoy the fresh environment inside the protected area and make a tour for sight-seeing by boat (MWTP for ASC is 134 thousand VND).

Table 5. Estimation of marginal willingness to pay (thousand VND)

\begin{tabular}{llll}
\hline \multirow{2}{*}{ Variable } & MWTP & \multicolumn{2}{c}{$95 \%$ confidence interval } \\
\cline { 3 - 4 } & & Lower limit & Upper limit \\
\hline ASC & 134 & 73 & 194 \\
crane & 155 & 93 & 216 \\
craft & 111 & 56 & 167 \\
fish1 & 222 & 142 & 303 \\
fish2 & 307 & 186 & 428 \\
\hline
\end{tabular}

Note. The $\overline{95 \% \text { confidence intervals were estimated using the Krinsky and Robb }(1986,1990) \text { procedure. }}$

The marginal values of ecotourism services valued by tourist are quite high, especially for fishing service (higher than the maximum tour cost of 200 thousand VND that had been offered in the questionnaire). This suggests that tourists are really interested in these ecotourism services and are willing to pay high prices for these services. The similar finding is also found in the study of tourist preferences for ecotourism attributes in South Africa (Chaminuka, 2012). The locals who are going to supply ecotourism services can consider this information to decide the price of services.

\subsection{Tourist's Preferences for Biodiversity Conservation}

The contrary effects of donation and price on tourist's utility reveal that although tourists prefer lower tour fee, 
they prefer higher donation amount for biodiversity conservation program (see Table 4). This interesting finding could be explained by following reasons. First, tourists are aware of responsible travel to nature area and hence they want to contribute to protect the natural environment and biodiversity conservation. The finding that donation has positive effect on tourist's utility is similar to some other studies. Carlsson and Martinsson (2001) used choice experiments to test whether or not hypothetical and actual willingness to pay differ, and revealed that donation had positive impacts on respondent's utility. Alpízar et al. (2014) researched people's preferences for mixed funding strategy including entrance fee and donation for conservation in a protected area in Costa Rica and discovered that donation increased respondent's utility. Second, because donation levels suggested in the choice set is reasonable (about one percent of the tour cost), respondents are easy to accept them. This second reason is demonstrated by tourist's marginal willingness to pay for donation (based on Equation (8)).

$$
\begin{aligned}
\text { MWTP }_{\text {donation }} & =\frac{\text { dprice }}{\text { ddonation }}=-\frac{\partial V / \text { donation }}{\partial V / \text { price }} \\
& =-\frac{0.0179 / 1 \text { thousandVNDforDonation }}{(-0.0061) / 1 \text { thousandVNDforTourCost }} \\
& =\frac{2.93 \text { thousandVNDforTourCost }}{\text { thousandVNDforDonation }}
\end{aligned}
$$

Tourists are willing to pay 2.93 thousand VND as tour cost to get 1 thousand VND of donation for biodiversity conservation. In other words, tourist's willingness to donate for biodiversity conservation activities is higher than the donation levels suggested in the questionnaire.

\section{Conclusion and Implication}

This paper researches about tourist preference for the hypothesis ecotourism in Phu My protected area. Choice experiments are applied to exam tourist's interest for ecotourism services such as crane-watching, visiting handicraft-market and fishing. Then, tourist's willingness to pay for each ecotourism activities is estimated. The paper also considers about tourist preferences for financial contribution to biodiversity and environment protection through tourist's donation.

The research results presents that tourists are interested in the hypothesis ecotourism in Phu My and prefer to enjoy crane-watching, craft-market visiting and fishing service. They are willing to pay for these activities with high price. This information is very useful for the managers and especially locals to plan for supplying ecotourism services as well as consider the prices of these services based on MWTP results. On the other hand, eco-education should be included in ecotourism. Information on importance of natural and biodiversity conservation can be provided through ecotourism service, for example Crane-watching service. Then, the managers can encourage tourists to contribute to the conservation of nature and biodiversity in this area.

Tourists declare that they are willing to donate for biodiversity conservation. Within the levels of donation suggested in the choice set, tourists prefer higher donation level. And they are willing to pay 2.93 thousand VND as tour cost to get 1 thousand VND of donation. This is optimistic information for the managers to have strategy for raising conservation fund. However, this study limits the levels of donation from 0 to 15 thousand VND. Higher levels of donation maybe lead to different results of tourist preference, which should be concerned in future researches.

In conclusion, this paper provides useful information for the managers and locals to develop ecotourism in Vietnam, which is contribute to the overall goal of social-economic development for local communities in rural area and sustainable conservation of nature and biodiversity in Vietnam. Finally, this paper also contributes to the limited literature on choice experiments in Vietnam, especially in ecotourism field.

\section{Acknowledgements}

The authors are grateful to the reviewer and the editor for their constructive comments and insightful suggestions. This research was supported by JSPS KAKENHI Grant Number 26292120.

\section{References}

Adamowicz, W., Louviere, J., \& Williams, M. (1994). Combining revealed and stated preference methods for valuing environmental amenities. Journal of Environmental Economics and Management, 26, 271-292. http://dx.doi.org/10.1006/jeem.1994.1017

Alpízar, F., Martinsson, P., \& Nordén, A. (2014). Do entrance fees crowd out donation for public goods? Evidence from a protected area in Costa Rica. Environment and Development Economics. http://dx.doi.org/10.1017/S1355770X14000485 
Biénabe, E., \& Hearne, R. R. (2006). Public preferences for biodiversity conservation and scenic beauty within a framework of environmental services payments. Forest Policy and Economics, 9(4), 335-348. http://dx.doi.org/10.1016/j.forpol.2005.10.002

Blamey, R. (1998a). Contingent Valuation and the activation of environmental norms. Ecological Economics, 24, 47-72. http://dx.doi.org/10.1016/S0921-8009(97)00586-7

Boxall, P. C., \& Macnab, B. (2000). Exploring the preferences of wildlife recreationists for features of boreal forest management: a choice experiment approach. Canadian Journal of Forest Research, 30, 1931-1941. http://dx.doi.org/10.1139/x00-128

Boxall, P. C., Adamowicz, W. L., Swait, J., Williams, M., \& Louviere, J. (1996). A comparison of stated preference methods for environmental valuation. Ecological Economics, 18, 243-253. http://dx.doi.org/10.1016/0921-8009(96)00039-0

Carlsson, F., \& Martinsson, P. (2001). Do Hypothetical and Actual Marginal Willingness to Pay Differ in Choice Experiments? - Application to the Valuation of the Environment. Journal of Environmental Economics and Management, 41, 179-192. http://dx.doi.org/10.1006/jeem.2000.1138

Chaminuka, P., Groeneveld, R. A., Selomane, A. O., \& van Ierland, E. C. (2012). Tourist preferences for ecotourism in rural communities adjacent to Kruger National Park: A choice experiment approach. Tourism Management, 33(1), 168-176. http://dx.doi.org/10.1016/j.tourman.2011.02.016

European Union Business and Biodiversity Platform. (2010). Agriculture Sector and Biodiversity Conservation: Best Practice Benchmarking. Retrieved from http://ec.europa.eu/environment/archives/business/assets/pdf/s ectors/FINAL_Agriculture.pdf

García-Herrera, J. J. (2014). Handbook of ecotourism in protected areas of Vietnam. Retrieved January 13, 2014, from http://mekongtourism.org/website/wp-content/uploadsds/downloads/2011/02/Handbook-of-Ecotouris m-in-Protected-Areas-of-Viet-Nam.pdf

Hanley, N., Wright, R. E., \& Adamowicz, V. (1998). Using Choice Experiments to Value the Environment. Environmental and Resource Economics, 11(3-4), 413-428. http://dx.doi.org/10.1023/A:1008287310583

Hearne, R. R., \& Salinas, Z. M. (2002). The use of choice experiments in the analysis of tourist preferences for ecotourism development in Costa Rica. Journal of Environmental Management, 65(2), 153-163. http://dx.doi.org/10.1006/jema.2001.0541

Hearne, R. R., \& Santos, C. A. (2005). Tourists' and locals' preferences toward ecotourism development in the Maya Biosphere Reserve, Guatemala. Environment, Development and Sustainability, 7(3), 303-318. http://dx.doi.org/10.1007/s10668-004-2944-3

Hensher, D. A., Rose, J. M., \& Greene, W. H. (2005). Applied Choice Analysis: A Primer. Cambridge University Press. http://dx.doi.org/10.1017/cbo9780511610356

Krinsky, I., \& Robb, A. L. (1986). On approximating the Statistical Properties of Elasticities. The Review of Economics and Statistics, 68(4), 715-719. http://dx.doi.org/10.2307/1924536

Krinsky, I., \& Robb, A. L. (1990). On approximating the Statistical Properties of Elasticities: a correction. The Review of Economics and Statistics, 72(1), 189-190. http://dx.doi.org/10.2307/2109761

Louviere, J., \& Hensher, D. A. (1982). On the Design and Analysis of Simulated Choice or Allocation Experiments in Travel Choice Modelling. Transportation Research Record, 890, 11-17.

Louviere, J., \& Woodworth, G. (1983). Design and Analysis of Simulated Consumer Choice or Allocation Experiments: An Approach Based on Aggregate Data. Journal of Marketing Research, 20, 350-367. http://dx.doi.org/

Naidoo, R., \& Adamowicz, W. L. (2005). Biodiversity and nature-based tourism at forest reserves in Uganda. Environment and Development Economics, 10, 159-178. http://dx.doi.org/10.1017/S1355770X0400186X

The Socialist Republic of Vietnam. (2003). Management Strategy for a Protected Area System in Vietnam to 2010.

Tisdell, C. A. (2003). Economic Aspects of Ecotourism: Wildlife-based Tourism and Its Contribution to Nature. Sri Lankan Journal of Agricultural Economics, 5(1), 83-95.

Tisdell, C. A., \& Wilson, C. (2002a). Economic, Educations and Conservation Benefits of Sea Turtle Based Ecotourism: A Study Focused on Mon Repos, CRC for Sustainable Tourism. Gold Coast Campus: Griffith 
University.

Triet, T., \& Caines, R. (2007). Towards Sustainable Rural Development: Combining Biodiversity Conservation with Poverty Alleviation - Case Study in Phu My Village, Kien Giang Province, Vietnam. Transition to a Resource-Circulating Society (pp. 181-190). Osaka University Press.

UNEP. (2002). Ecotourism: Principles, Practices \& Policies for Sustainability. Retrieved from http://www.unep.fr/shared/publications/other/WEBx0137xPA/part-one.pdf

Vesterlund, L. (2006). Why do people give? Retrieved from http://www2.pitt.edu/ vester/whydopeoplegive.pdf

\section{Copyrights}

Copyright for this article is retained by the author(s), with first publication rights granted to the journal.

This is an open-access article distributed under the terms and conditions of the Creative Commons Attribution license (http://creativecommons.org/licenses/by/3.0/). 